\title{
Botanical Exploration and Crater Vegetation Survey of Mt. Galunggung, West Java
}

\author{
Musyarofah Zuhri ${ }^{1 *}$, Harry Wiriadinata ${ }^{2}$, Ratna Suti Astuti ${ }^{3}$, Supan Hadiwaluyo ${ }^{3}$, Syamsudin ${ }^{1}$
}

\author{
${ }^{1}$ Cibodas Botanical Garden-Indonesian Institute of Sciences (LIPI), Cianjur, Indonesia \\ ${ }^{2}$ Biology Research Center, Indonesian Institute of Sciences (LIPI), Bogor, Indonesia \\ ${ }^{3}$ Conservation Center of Botanical Gardens, Indonesian Institute of Sciences (LIPI), Bogor, Indonesia
}

\section{ABSTRACT}

Botanical exploration at Mt. Galunggung protected forest, West Java was conducted in June 2014. This study aimed to collect plant living specimen for ex-situ conservation purpose of Kuningan Botanic Garden and to conduct vegetation analysis in crater area. Random inventory method at $600-1200 \mathrm{~m}$ above sea level was used to collect plant in that area. Vegetation analysis of tree, shrub and herb were used line transect methods. 273 collection numbers of plant living species were collected from Mt. Galunggung, which consist of 213 species, 143 genus and 72 families. Orchidaceae, Moraceae, Euphorbiaceae, Arecaceae and Lauraceae were the most collected plant families from Mt. Galunggung. In crater area were collected a lot of pioneer plants, such as dawola (Trema cannabina Lour.), paku tiang (Cyathea spp.), nangsi (Villebrunea rubescens (Blume) Blume), muncang cina (Ostodes paniculata Blume), mara (Macaranga tanarius (L.) Mull.Arg.), and kareumbi (Homalanthus populneus (Geiseler) Pax). Furthermore, in secondary remnant forests were collected the typical plants of Java mountains such as saninten (Castanopsis argentea (Blume) A.DC.), puspa (Schima wallichii Choisy) and some of tree seedlings from Lauraceae family. Vegetation affected by eruption in Mt. Galunggung is in early stage of forest succession and still develops to next stage of succession. Tree, shrub and herb in the crater area were dominated by Cyathea contaminans (Wall. Ex Hook.) Copel., Calliandra callothyrsus Meisn., and Ageratina riparia (Regel) R.M.King \& H.Rob. with $H^{\prime}$ was $0.35,0.22$ and 0.30 respectively.

Keywords: Botanical exploration, crater vegetation, forest succession, Mt. Galunggung, pioneer plant

\section{INTRODUCTION}

Botanical gardens offer an authentic experience of the world's natural heritage. It comes from their plant collections which apparent in medicinal, taxonomic and economic purposes. Furthermore, botanic gardens have a particular source of power derived from the economic, environmental, social and cultural values of their botanical explorations for plant collections [1]. Plant exploration is common method for botanist to discover, collect and move plant from wild environmental to botanic garden for plant conservation purpose. Botanic gardens play a critical role as the last defense of plant extinction which might caused by deforestation, poverty, climate change, over-harvesting and land use change.

Java mountain forests are high in floristic richness

\footnotetext{
${ }^{*}$ Corresponding author:

Musyarofah Zuhri

Cibodas Botanical Garden-Indonesian Institute of Sciences (LIPI),

Jl. Kebun Raya Cibodas, Cipanas-Cianjur 43253, Indonesia

E-mail: musyarofah.zuhri@lipi.go.id
}

[2]. But intense pressure from neighbor community was raising threat to their functions and values. As one of active volcano mountain in Java, Mt. Galunggung has climax primer forest community until it was erupted in 1982-1983 and lead to ecosystem recovery $[3,4]$. It was erupted very destructive over both short and long period [5]. After 31 years of Mt. Galunggung last eruption, vegetation succession shows plant colonized by pioneer species and other plant species. Botanic exploration has not previously done in this area. This botanical exploration aimed to collect plant living specimen for ex-situ conservation purpose in Kuningan Botanic Garden and to conduct vegetation analysis in crater area that affected by eruption.

\section{How to cite:}

Zuhri M, Wiriadinata H, Astuti RS, Hadiwaluyo S, Syamsudin (2016) Botanical exploration and crater vegetation survey of Mt. Galunggung, West Java. J. Trop. Life. Science 6 (2): 69 78 . 


\section{MATERIALS AND METHODS}

Mt. Galunggung is an active volcano located at Tasikmalaya District, West Java, Indonesia about 100 $\mathrm{km}$ southeast of Bandung. The last major eruption occurred 9 months in 1982-1983 and caused both catastrophic destruction and primary succession. It peak is located at $107^{\circ} 54^{\prime} 32^{\prime \prime}-108^{\circ} 28^{\prime} 5^{\prime \prime} \mathrm{E}$ and $7^{\circ} 03^{\prime} 00^{\prime \prime}$ $7^{\circ} 48^{\prime} 10^{\prime \prime S}$ with elevation $2,168 \mathrm{~m}$ asl. Forested area in Mt. Galunggung is protected forest (5,012 ha) and pine forest $(5,473 \mathrm{ha})$. There are also recreational purpose area (40 ha) which perform natural tourism, i.e. crater landscape and hot spring. The main authority managing in this area is Forest Management Unit Tasikmalaya, PT. Perhutani Unit II West Java. This study was mainly conducted in the mixed forest and crater vegetation which affected by eruption (Table 1 ).

\section{Botanical exploration}

Plants were collected in the natural habitat with priority for endemic, unique, threatened and potentially have medicinal, ornamental and timber uses. Plant exploration was conducted for 3 weeks in June 2014 using survey method for gathering plant material, i.e. plant seedlings, seeds and cuttings. Seedlings were taken by digging soil around plant and pull it gently; mature seeds were harvested and separated from fleshy fruit; and shoot cuttings were taken for plant which not produce both of seedling and seed. Afterwards, plant material was transport to base camp for labeling and handling to support plant alive before carrying to nursery of Kuningan Botanic Garden. Interviews were conducted to local residents about the benefit of collected plants.

Plant was identified directly in the field by spotcharacters of morphological characteristics such as habit, stem or branch, exudate, smell, indument, glands, stipules, petiole or rachis, leaf form and arrangement, inflorescence, flower, fruit and seed forms. Supporting data was recorded, i.e. coordinate and climatic factors (air temperature, relative humidity, soil $\mathrm{pH}$ and soil humidity). Herbarium voucher was collected for plants which unidentified in the field for further identified in Herbarium Bogoriense (BO) by compared with herbarium speciment collection. A good specimen includes stems, leaves, flowers and fruits. Absence both of flower and fruit make identification process was so difficult. For that case, plant identification is being postponed until plants in nursery reach mature form or produce flowers and fruits.

Due to plant adaptation purpose, plants in the nursery were covered by clear plastic in the net house to prevent excessive evaporation and maintain humidity so it can obtain high survival rate. Epiphytic plants were attached on coconut husk which has good water storage capacity and it placed in the shaded area. Watering was conducted regularly especially during dry season. Plants condition, number of live and dead plants were observed weekly until a period of plants well adapted to local conditions.

\section{Vegetation survey}

Plant diversity assessment was conducted using plot-based sampling by transect line method in crater area which affected by eruption. Line transect was made perpendicular to contour. Measurements were conducted for all species of life forms, i.e. tree, shrub and herb. The 0.1 ha sampling plot was nested in which size of the outermost plot was $10 \times 10 \mathrm{~m}^{2}$ (for trees with $\mathrm{dbh} \geq 10 \mathrm{~cm}$ ) enclosing $5 \times 5 \mathrm{~m}^{2}$ plot (for trees with $\mathrm{dbh} \leq 10 \mathrm{~cm}$ and shrubs) and $1 \times 1 \mathrm{~m}^{2}$ plot (for herbs). The main parameter was measured in each plot, i.e. kind of species, abundance, dbh and height. Abundance was counted for each plant individu which present in the plots. Dbh was measured for trees and shrubs using diameter tape and it height was measured using hagameter.

The data was subsequently analyzed to calculate relative density, frequency and dominance, important value index (IVI) and Shannon-Weaver diversity index using following formula $[6,7,8]$.

Relative Density $=\frac{\text { Number of individual of the species }}{\text { Number of individual of all the species }} \times 100 \%$

Relative Frequency $=\frac{\text { Number of occurence of the species }}{\text { Number of occurence of all the species }} \times 100 \%$

Relative Dominance $=\frac{\text { Total basal area of the species }}{\text { Total basal area of all the species }} \times 100 \%$

Important Value of Index $(I V I)=R D n+R F+R D o$

RDn : Relative density

RF : Relative frequency

RDo : Relative dominance

Shannon - Weaver Diversity Index $\left(H^{\prime}\right)=-\sum_{i=1}^{n} p i \ln p i$

n : Richness

pi : Proportion of individuals belonging to the $\mathrm{i}^{\text {th }}$ species 
Table 1. Location of botanical exploration

\begin{tabular}{|c|c|c|c|}
\hline Location & Vegetation & Coordinate & Altitude range ( $m$ asl) \\
\hline $\begin{array}{l}\text { W. Java: Tasikmalaya District, Sukaratu Subdistrict, } \\
\text { Linggajati Village, Gedong Nyungcung Sub Village }\end{array}$ & Secondary forest & $108^{\circ} 06^{\prime} 29.1^{\prime \prime E}$ and $7^{\circ} 13^{\prime} 20.3^{\prime \prime S}$ & $760-1160$ \\
\hline $\begin{array}{l}\text { W. Java: Tasikmalaya District, Sukaratu Subdistrict, } \\
\text { Linggajati Village, Gedong Nyungcung Sub Village }\end{array}$ & Crater vegetation & $\begin{array}{l}108^{\circ} 04^{\prime} 39.2^{\prime \prime}-108^{\circ} 04^{\prime} 44.5^{\prime \prime} \mathrm{E} \text { and } \\
7^{\mathrm{o}} 15^{\prime} 42^{\prime \prime}-7^{\mathrm{o}} 15^{\prime} 38.4^{\prime \prime} \mathrm{S}\end{array}$ & $1118-1229$ \\
\hline $\begin{array}{l}\text { W. Java: Tasikmalaya District, Sukaratu Subdistrict, } \\
\text { Sinaga Village, Singemplong Sub Village }\end{array}$ & Secondary forest & $108^{\circ} 06^{\prime} 16.2^{\prime \prime} \mathrm{E}$ and $7^{\circ} 15^{\prime} 37.6^{\prime \prime} \mathrm{S}$ & $731-750$ \\
\hline $\begin{array}{l}\text { W.Java: Tasikmalaya District, Cisayong Subdistrict, } \\
\text { Sinaga Village, Singemplong Sub Village }\end{array}$ & Secondary forest & $\begin{array}{l}108^{\circ} 06^{\prime} 51.5^{\prime \prime}-108^{\circ} 06^{\prime} 18^{\prime} \mathrm{E} \text { and } \\
7^{\mathrm{o}} 16^{\prime} 43.1^{\prime \prime}-7^{\mathrm{o}} 15^{\prime} 34^{\prime \prime} \mathrm{S}\end{array}$ & $593-780$ \\
\hline $\begin{array}{l}\text { W.Java: Tasikmalaya District, Cisayong Subdistrict, } \\
\text { Santana Mekar Village, Cicurug Sub Village }\end{array}$ & Secondary forest & $108^{\circ} 07^{\prime} 8.7^{\prime \prime} \mathrm{E}$ and $7^{\mathrm{o}} 15^{\prime} 15.5^{\prime \prime} \mathrm{S}$ & $727-790$ \\
\hline $\begin{array}{l}\text { W.Java: Tasikmalaya District, Cisayong Subdistrict, } \\
\text { Sukamukti Village, Cipeteuy Sub Village }\end{array}$ & Secondary forest & $108^{\circ} 06^{\prime} 49.2^{\prime \prime} \mathrm{E}$ and $7^{\circ} 14^{\prime} 16^{\prime \prime} \mathrm{S}$ & $900-950$ \\
\hline $\begin{array}{l}\text { W.Java: Tasikmalaya District, Kadipaten Subdistrict, } \\
\text { Kadipaten Village, Ciselang Sub Village }\end{array}$ & Secondary forest & $108^{\circ} 04^{\prime} 11^{\prime \prime E}$ and $7^{\circ} 7^{\prime} 37.6^{\prime \prime S}$ & $1200-1260$ \\
\hline
\end{tabular}

\section{RESULTS AND DISCUSSION}

Preceding biological research in Mt. Galunggung was very limited which could give overview of vegetation in Mt. Galunggung to botanical exploration team. Only a bachelor thesis was describing vegetation succession of tree and understorey species in Mt. Galunggung [4]. It reports vegetation in Mt. Galunggung dominated by Parasponia parviflora, Eupatorium riparium, Cyathea contaminans, Micania scandens, Sellaginella plana and Diplazium esculentum. These data indicate Mt. Galunggung is in the early stage of forest succession.

\section{Plant material collection}

Botanical exploration was collected 273 numbers of plant living collections ( 1,827 specimens) which consist of 213 species, 143 genera, and 72 families. There were 22 collection numbers of orchid. Plant living collections were collected from 7 sites covering crater area affected eruption, mixed, and forest. From the field, plants were transported to nursery for adaptation process before it planted in Kuningan Botanic Garden. After 4 months in nursery the survival rate of plant was reach $83.5 \%$ (Table 2). The complete list of species showed in Appendix 1 [9].

The most collected family was Orchidaceae, Moraceae, Euphorbiaceae, Arecaceae and Lauraceae. Both of Ficus fistulosa and F. fulva were collected from crater area. Meanwhile, other Moraceae member was collected from mixed forest, i.e. F. septica, F. variegata,
F. ampelas, F. padana, Ficus spp., Arthocarpus cempeda, and A. heterophylla. Ficus had a large member of species which distributed in tropics and temperate area with the highest diversity in Southeast Asia, Melasia and South America tropics [10,11]. As a keystone species in tropical rain forest, Ficus attends in lowland and highland and some of Ficus species are pioneer which can live in dry habitat $[12,13]$.

Member of Euphorbiaceae was collected in crater area and mixed forest and some of them were pioneer species, i.e. Homalanthus populneus, Macaranga tanarius and Ostodes paniculata. The numbers of pioneer species in regional floras, as well as in communities, are small and they are represented by a limited number of plant families [14]. Early succession was dominated by pioneer woody species and Macaranga is the genus par excellence of pioneer trees [15]. Furthermore, Macaranga and Homalanthus are prominent in early stages of secondary succession in montane forests [16].

Arecaceae was collected from shady and closed area in clump, tree form and woody climber at mixed forest i.e. Arenga pinnata, Calamus javensis, Caryota mitis, Plectocomia elongata, Pinanga coronata, P. elongata, Daemonorops melanochaetes, Daemonorops sp., Pinanga sp., Nenga sp., and Caryota sp. Palms (Arecaceae/Palmae) are diverse and abundant and one of the most characteristic and ecologically important components of tropical rain forest worldwide [17,18]. A. pinnata is native to Southeast Asia, occurring in tropi- 
cal rainforest and dry forest. Usually it grows close to human settlements where anthropic propagation plays a major role. Otherwise it prefers secondary forest at the border of primary rainforest [19]. Pinanga sp. was collected from edge of mixed forest at 1,160 m asl with height reached $15 \mathrm{~m}$, solitary, leaves pinnate, up to $2 \mathrm{~m}$ long, leaflets 30 in pairs, bole straight, erect, unarmed, smooth and green brownish. It was unidentified to species level because mature fruits weren't found but it might be $P$. arinase which described as a new species. Pinanga in Java and Bali are recognized three species, i.e. $P$. javana and $P$. arinase are single-stemmed and $P$. coronata is clustered [20].

There were 11 species of Lauraceae collected in crater and mixed forest in open and closed area at 731$1200 \mathrm{~m}$ asl. The useful plants among these species were i.e. Neolitsea javanica ( $k i$ teja), Litsea roxburghii (tangkalak), and Actinodaphne cuneata (huru payung). $N$. javanica is native to Java and its bark is useful for insect repellent material. The wood of L. roxburghii is white, has timber value with medium quality for constructions, its fruits are round, fleshy, edible and red after ripening. A. cuneata also has timber value for constructions.

Only one species of rare plant was collected from Mt. Galunggung area which categorized as vulnerable (VU) based on IUCN redlist ver. 2014.2, i.e. Saurauia cauliflora (ki leho) [21]. It is native to West Java and it threatened by forest degradation and human pressure. $S$. cauliflora is small tree up to $10 \mathrm{~m}$ tall; lamina serrated, young leaves red and covered by scales, leaf tip tapered; flowers in assemble, white to red pale, pendulant, cauliflora; fruits pale green to white, globose, discharge when pressed; seeds black, minute, numerous. It was found in riverside at $780 \mathrm{~m}$ asl and collected as seedlings.

Some of plants have herbal medicinal use i.e. Chloranthus officinalis (keras tulang) as aphrodisiac, Erythrina subumbrans (dadap cangkring) as cough cure, Sterculia coccinea (hantap) as heatiness cure, Spatholobus ferrugineus as laxative cure, Evodia macrophylla for itchy, Gaultheria fragrantissima as aromatic oil, Musa troglodytarum for kidney cure and diabetes cure, Trichosanthes villosa as cold medicine and diarrhea cure, and Villebrunea rubescens for eye pain cure and increasing production of breast milk. C. officinalis is understorey shrub, up to $1 \mathrm{~m}$ tall, leaves are smooth obovate-oblong or elliptic, flowers are minute and fruit is white, juicy with a relatively large seed. All plant parts have a camphoraceous odor and bitter, aromatic taste. Root of C. officinalis is used for aphro- disiac and leaves of $C$. officinalis can be used for tea made.

Some of fruit plants are edible, i.e. Rubus rosaefolius (arben), Smilax leucophylla (canar), Psidium sp. (jambu nagri), Castanopsis argentea (saninten), Arenga pinnata (aren), Passiflora foetida (konyal), and Litsea roxburghii (tangkalak). Jambu nagri is small tree, up to $8 \mathrm{~m}$ tall; lamina thick, lanceolate, intramarginal vein, on top green shiny; flowers clustered, dark to pale green; fruits minute and plentiful. It was only found in a human settlement at Kampong Raja Kalapa, Sida Mukti Village, Tasikmalaya at $820 \mathrm{~m}$ asl and it was cultivated and planted in the front yard. Jambu nagri was collected in seedling form. Furthermore, several plants have potency as a timber, i.e. Actinodaphne cuneata (huru payung), C. argentea (saninten), Manglietia glauca (manglid), Agathis dammara (damar), Hibiscus tiliaceus, Olea javanica (ki ranca), Neolitsea javanica (ki teja), Bridellia glauca (kanyere), Homalanthus populneus (kareumbi), Litsea roxburghii (tangkalak), and Syzygium ampliflorum (ki jangkar).

\section{Crater plant diversity}

Variation on vegetation composition in Mt. Galunggung crater area can be seen from the dominant species presented in Table 3,4 and 5. Only 3 tree species was found at tree form, i.e. Trema cannabina (dawola), Cyathea contaminans (pakis pohon) and Piper aduncum (seuseureuhan). Based on Important Value Index (IVI), tree form dominated by $C$. contaminans. The dominance of $C$. contaminans indicates that this species is able to withstand the environmental changes caused by volcanic eruption. T. cannabina is small tree or shrub, up to $4 \mathrm{~m}$ tall; lamina hairy rough with toothed edges, leaf base composed 3 veins, petiole downy; flowers multiples of 5; fruits drupe, green to orange while ripening, attached to the axillary. It was found abundantly along the stairway leading to the crater up to $1,208 \mathrm{~m}$ asl. $T$. cannabina is a pioneer tree species in naturally regenerated vegetation after forest fire along with $P$. aduncum [22].

Dominant species of shrub and herb were Calliandra calothyrsus (kaliandra) and Agerantina riparia (tekan) respectively. Shrub and herb diversity in area affected by eruption at Mt. Galunggung indicated that the recovery of understorey vegetation occurred considerably quickly. C. calothyrsus was deliberately planted for reforestation purpose and also to decrease soil erosion. But it was consequences in ecological aspect since its canopy covered tightly and caused forest 
Table 2. Recapitulation of botanical exploration after 4 months in nursery of Kuningan Botanic Garden

\begin{tabular}{llcccccc}
\hline \multirow{2}{*}{ Group of plants } & \multirow{2}{*}{$\begin{array}{c}\text { Prior } \\
\text { collection }\end{array}$} & $\begin{array}{c}\text { Collection } \\
\text { numbers which }\end{array}$ & $\begin{array}{c}\text { Number of } \\
\text { family/genus }\end{array}$ & $\begin{array}{c}\text { Identified } \\
\text { collection }\end{array}$ & \multicolumn{2}{c}{ Unidentified collection numbers } \\
\cline { 6 - 8 } & numbers & cannot survive & & Family & $\begin{array}{c}\text { Genus } \\
\text { unidentified }\end{array}$ & $\begin{array}{c}\text { Species } \\
\text { unidentified }\end{array}$ & unidentified \\
\hline Common plants & 251 & 44 & $72 / 138$ & 145 & - & 10 & 52 \\
Orchid & 22 & 1 & $1 / 12$ & 12 & - & 1 & 8 \\
\hline
\end{tabular}

Table 3. Tree diversity of crater area as measured by Important Value Index (IVI) and Shannon Index (H')

\begin{tabular}{|c|c|c|c|c|c|c|c|c|}
\hline Local name & Family & Species & & $\begin{array}{c}\text { Relative } \\
\text { density (\%) }\end{array}$ & $\begin{array}{c}\text { Relative } \\
\text { frequency (\%) }\end{array}$ & $\begin{array}{c}\text { Relative basal } \\
\text { area (\%) }\end{array}$ & $I V I$ & $H^{\prime}$ \\
\hline Dawola & Urticaceae & Trema cannabina Lour. & & 26.32 & 44.44 & 21.78 & 92.54 & 0.35 \\
\hline Pakis pohon & Cyatheaceae & $\begin{array}{l}\text { Cyathea contaminans } \\
\text { Hook.) Copel. }\end{array}$ & (Wall. ex & 71.93 & 50.00 & 78.19 & 200.12 & 0.24 \\
\hline Seuseureuhan & Piperaceae & Piper aduncum L. & & 1.75 & 5.56 & 0.03 & 7.34 & 0.07 \\
\hline & & Total & & 100 & 100 & 100 & 300 & 0.66 \\
\hline
\end{tabular}

Table 4. Shrub diversity of crater area as measured by Important Value Index (IVI) and Shannon Index (H')

\begin{tabular}{|c|c|c|c|c|c|c|}
\hline Local name & Family & Species & Relative frequency (\%) & Relative dominance (\%) & $I V I$ & $H^{\prime}$ \\
\hline Harendong gede & Melastomataceae & Melastoma malabathricum L. & 20 & 3.65 & 23.65 & 0.31 \\
\hline Kaliandra & Leguminosae & Calliandra calothyrsus Meisn. & 60 & 95.70 & 155.70 & 0.22 \\
\hline Seuseureuhan & Piperaceae & Piper aduncum L. & 20 & 0.65 & 20.65 & 0.19 \\
\hline \multicolumn{3}{|c|}{ Total } & 100 & 100 & 200 & 0.72 \\
\hline
\end{tabular}

Table 5. Herb diversity of crater area as measured by Important Value Index (IVI) and Shannon Index (H')

\begin{tabular}{|c|c|c|c|c|c|c|}
\hline Local name & Family & Species & $\begin{array}{l}\text { Relative } \\
\text { frequency }(?\end{array}$ & $\begin{array}{c}\text { Relative } \\
\text { dominance (\%) }\end{array}$ & $I V I$ & $H^{\prime}$ \\
\hline Teklan & Compositae & $\begin{array}{l}\text { Ageratina riparia (Regel) R.M.King \& } \\
\text { H.Rob. }\end{array}$ & 27.72 & 30.60 & 58.32 & 0.30 \\
\hline Kaliandra & Leguminosae & Calliandra calothyrsus Meisn. & 8.91 & 11.94 & 20.85 & 0.17 \\
\hline Jukut pait & Poaceae & Axonopus compressus (Sw.) P.Beauv & 15.84 & 8.96 & 24.80 & 0.17 \\
\hline Eurih/lalang & Poaceae & Imperata cylindrica (L.) Raeusch. & 9.90 & 8.96 & 18.86 & 0.16 \\
\hline Harendong gede & Melastomataceae & Melastoma malabathricum L & 3.96 & 6.72 & 10.68 & 0.15 \\
\hline Pakis & Nephrolepidaceae & Nephrolepis sp. & 6.93 & 5.97 & 12.90 & 0.14 \\
\hline Harendong bulu & Melastomataceae & Clidemia hirta (L.) D. Don & 5.94 & 5.97 & 11.91 & 0.11 \\
\hline Kirinyuh & Compositae & Eupatorium inulifolium Kunth & 3.96 & 4.48 & 8.44 & 0.09 \\
\hline Aawian & Poaceae & Pogonatherum paniceum (Lam.) Hack. & 6.93 & 4.48 & 11.41 & 0.09 \\
\hline Anggrek tanah & Orchidaceae & sp.1 & 1.98 & 2.99 & 4.97 & 0.05 \\
\hline- & Poaceae & sp. 2 & 1.98 & 2.99 & 4.97 & 0.05 \\
\hline Harendong leutik & Melastomataceae & Melastoma sp. & 0.99 & 1.49 & 4.46 & 0.03 \\
\hline Jukut palias & Poaceae & Pogonatherum crinitum (Thunb.) Kunth & 2.97 & 1.49 & 4.46 & 0.03 \\
\hline Seuseureuhan & Piperaceae & Piper aduncum $\mathrm{L}$. & 0.99 & 1.49 & 2.48 & 0.03 \\
\hline \multirow[t]{2}{*}{-} & Rubiaceae & Spermacoce laevis Lam. & 0.99 & 1.49 & 2.48 & 0.03 \\
\hline & & Total & 100 & 100 & 200 & 1.58 \\
\hline
\end{tabular}


floor becomes empty. Introduced exotic plant may alter normal succession [23].

Plant diversity in Mt. Galunggung which affected by volcanic eruption was higher than Mt. Papandayan mountain forest. Four years after last eruption of $\mathrm{Mt}$. Papandayan (peak 2,325 m asl) in 2002, ecological study in Mt. Papandayan did not found existance of tree species and diversity index of shrubs and herbs were 0.28 and 1.65 respectively [24]. It was slightly lower than diversity index of trees, shrubs and herbs of Mt. Galunggung study area, i.e. 0.66, 0.72 and 1.58 respectively. It was suggested that the vegetation in $\mathrm{Mt}$. Galunggung still develop to the next stage of succession. As studied in Rakata, the primary sucession shows successive dominance of cryptograms, chiefly algae and ferns, and later of grasses and other herbaceous plants and finally of trees [25]. Meanwhile, the presence of moss from genus Campylopus was indicated that the vegetation is in early stage of forest succession. In crater area of Mt. Galunggung, Campylopus sp. was frequent in open area and sandy soil.

Many exotic plants was occupied area affected by eruption, i.e. Ageratina riparia (teklan), Imperata cylindrica (eurih/lalang), Clidemia hirta (harendong bulu) and Euparotium inulifolium (kirinyuh). Weeds are increasingly common on volcanos and the presence of weeds in volcanic landscapes is inevitable and plant communities are assembled from the available components [23]. The presence of exotic plants also gives overview that vegetation in Mt. Galunggung was influenced by volcanic eruption and anthropogenic through tourism activity.

\section{CONCLUSION}

Botanical exploration was collected 273 numbers of plant living collections ( 1,827 specimens) which consist of 213 species, 143 genera and 72 families from Mt. Galunggung. The most collected family was Orchidaceae, Moraceae, Euphorbiaceae, Arecaceae and Lauraceae. After 4 months adaptation period in nursery of Kuningan Botanical Garden the survival rate of plant was reached $83.5 \%$. One species of rare plant was collected from Mt. Galunggung area that is $S$. cauliflora (ki leho) which categorized as vulnerable (VU). Some of plants were have herbal medicinal use, edible fruits and also potency as timber. Vegetation affected by eruption in Mt. Galunggung was in early stage of forest succession and still develops to next stage of succession. Tree, shrub and herb in the crater area were dominated by $C$. contaminans, $C$. callothyrsus, and $A$. riparia with $\mathrm{H}^{\prime} 0.35,0.22$ and 0.30 respectively.

\section{ACKNOWLEDGMENT}

Thanks are due to Plant Conservation Center of Botanic Gardens, Indonesian Institute of Sciences (LIPI) for providing funds to conduct the study and Forest Management Unit Tasikmalaya, PT. Perhutani Unit II West Java for providing permits to explore Mt. Galunggung. The authors also thank and appreciate local communities for their cooperation and patience in providing the information and hospitality while undertaking surveys.

\section{REFERENCES}

1. Forbes S (2008) How botanic gardens changed the world. Presented at the history and future of social innovation conference: 19-21 June 2008; Adelaide. Hawke Research Institute for Sustainable Societies, University of South Australia. Australia.

2. Van Steenis CGGJ (2010) Flora Pegunungan Jawa. Bogor: Pusat Penelitian Biologi - LIPI.

3. Gourgaud A, Camus G, Gerbe MC et al (1989) The 198283 Eruption of Galunggung (Indonesia): A case study of volcanic hazards with particular relevance to air navigation. Volcanic Hazards. IAVCEI Proceedings in Volcanology 1:151-162.

4. Susanto A (2002) Suksesi vegetasi jenis pohon dan tumbuhan bawah pasca letusan Gunung Galunggung. Bachelor Thesis. Forestry Faculty, Institut Pertanian Bogor.

5. Bronto S (1989) Volcanic geology of Galunggung, West Java, Indonesia. Thesis. University of Caterbury.

6. Shannon CE, Weaver, W (1949) The mathematical theory of communication. Urbana, University of Illinois Press.

7. Stiling P (2002) Ecology: Theories and applications. New Jersey, Prentice-Hall Inc.

8. Spellerberg IA, Fedor PJ (2003) A tribute to Claude Shannon (1916-2001) and a plea for more rigorous use of species richness, species diversity and the 'Shannon-Wiener' index. Global Ecology \& Biogeography 12: 177-179.

9. Zuhri M, Wiriadinata H, Astuti RS et al (2014) Konservasi ex-situ tumbuhan: eksplorasi dan flora gunung Galunggung dalam rangka pengayaan koleksi Kebun Raya Kuningan. Laporan Teknis Kegiatan. Bogor: PKT Kebun Raya - Lembaga Ilmu Pengetahuan Indonesia.

10. Sonibare MA, Jayeola AA, Egunyomi A (2004) A morphometric Analysis of the Genus Ficus Linn. (Moraceae). African Journal of Biotechnology 3(4): 229-235.

11. Janzen DH (1979) How to be a Fig. Annual Review Ecological Systems 10:13-51.

12. Lee $\mathrm{SH}, \mathrm{Ng} \mathrm{ABC}$, Ong $\mathrm{KH}$ et al (2013) The status and distribution of Ficus hispida L.f. (Moraceae) in Singapore. Nature in Singapore 6: 85-90. 
13. van Balgooy, MMJ (1998) Malesian seed plants, volume 2 potraits of tree families. Leiden, The Netherlands: Rijksherbarium/Hortus Botanicus.

14. Whitmore TC (1984) Gap size and species richness in tropical rain forests. Biotropica 16: 239.

15. Whitmore TC (1975) Tropical rain forests of far east. Oxford, Clarendon Press.

16. van Valkenburg JLCH, Ketner P (1994) Vegetation changes following human disturbance of mid-montane forest in the Wau area, Papua New Guinea. Journal of Tropical Ecology 10: 41-54.

17. Vormisto J, Svenning JC, Hall P et al (2004) Diversity and dominance in palm (Arecaceae) communities in terra firme forests in the western Amazon basin. Journal of Ecology 92: $577-588$.

18. Couvreur TLP, Forest F, Baker WJ (2011) Origin and global diversification patterns of tropical rain forests: inferences from a complete genus-level phylogeny of palms. BMC Biology 9 (44): 1-12.

19. World Agroforestry (2014) Agroforestree database: A tree reference and selection guide version 4.0. http://www.worldagroforestry.org/, accessed 2014.
20. Witono JR, Mogea JP, Somadikarta S (2002) Pinanga in Java and Bali. Palms 46(4): 193-202.

21. IUCN (2014) The IUCN red list of threatened species version 2014.2. http://www.iucnredlist.org/, accessed 2014.

22. Hiratsuka M, Toma T, Diana R, Hadriyanto D, Morikawa $Y$ (2006) Biomass recovery of naturally regenerated vegetation after the 1998 forest fire in East Kalimantan, Indonesia. Jarq 40(3): 277-282.

23. del Moral R, Grishin SYu In: Walker LR, ed. (1999) Volcanic disturbances and ecosystem recovery. Ecosystems of Disturbed Ground, Ecosystem of the world. Amsterdam: Elsevier.137-155.

24. Sulistyawati E, Sungkar RM, Maryani E et al (2006) The biodiversity of Mount Papandayan and the threats. Paper presented on International Interdisiplinary Conference Volcano International Gathering 2006, "100 years Merapi Paroxysmal Eruption", Volcano: Life, Prosperity and Harmony: September 7, 2006; Yogyakarta.

25. Richards PW (1988) The tropical rain forest: An ecological study. With contributions by Walsh RPD, Baillie IC, GreigSmith P. UK: Cambridge University Press. 